\title{
Challenges of mathematics learning with heuristic strategies
}

\author{
Munaya Nikma Rosyada ${ }^{*}$, Heri Retnawati ${ }^{1}$ \\ ${ }^{1}$ Universitas Negeri Yogyakarta, Indonesia \\ $\triangle$ munayanikma38@gmail.com*
}

\section{Article Information \\ Submitted April 20, 2021 \\ Revised May 11, 2021 \\ Accepted May 12, 2021}

\author{
Keywords \\ Challenges, \\ Heuristic Strategy, \\ Mathematics Learning, \\ Problem Solving.
}

\begin{abstract}
Problem solving is an essential aspect of students' mathematical activities. This ability could practice by using heuristic strategies in learning. Besides, these are assured to be able to promote metacognitive skills. In the implementation, teachers faced several challenges. This research aims to describe the challenges of teachers in implementing learning with heuristic strategies. This research is a descriptive qualitative. Participants of this research were 12 junior high school mathematics teachers from 12 high schools in the Special Region of Yogyakarta and Central Java. Data collection was taken by questionnaire and added with documentation. Data were analyzed using the Miles \& Huberman stage-data reduction, data display, and drawing conclusion/verification. The data then validated using triangulation technique. The results revealed that some of teacher has already implement heuristic strategy in the learning process, but unable to define the heuristic strategy correctly. In its implementation, teachers experience several obstacles. These obstacles were found in providing non-routine problems to students, solving problems by students, and in discussions conducted to solve problems.
\end{abstract}

\section{INTRODUCTION}

In the 21 st century, every individual needs to have skills to support daily life, both in the social, professional, and educational fields. These skills are described by (Scott, 2017) as 21st-century skills consist of three principal elements, namely learning and innovation skills, life and career skills, as well as information, media, and technology skills. Learning and innovation skills consist of communication, collaboration, critical thinking, and creativity skill (4CS). These four skills are the key factors in education (Smit, 2016), especially for the implementation of mathematics education. To facilitate individuals, especially students, it is necessary to hold the learning that can practice these skills, and it is hoped that students could solve problems effectively (Irhamna, 2017).

Problem solving is an important aspect of mathematics learning process, both teaching and learning (Abdullah et al., 2019). NCTM (2000) defines problem solving as an integrated part of mathematics learning. This activity acts as an exercise for students to build and develop their cognitive abilities (Syahlan, 2017). The problems given by the teacher have a positive impact on training students' critical thinking skills (Singh et al., 2018). Broadly speaking, problemsolving activities are an alternative way to sharpening critical thinking. By implication of this statement, (Ang \& Lau, 2019) affirmed that critical thinking is required in solving mathematical problems.

According to (Lester et al., 1989), problem solving is a complex cognitive activity that requires more than directly applying mathematical content knowledge. It can be seen that some students were not fluent in problem solving due to a lack of chances to work at this. to produce 
students who dare to solve problems, the teacher could provide more extra tools for problem solving and giving more opportunities to learn by each other. That way, students can determine problem-solving steps without fear and concern (Vongyai \& Noparit, 2019). To be able to solve problems effectively, students need to be familiarized with problem-solving/heuristic (Ang \& Lau, 2019). One effort that can be done is implementing a heuristic strategy (Kiong et al., 2017; Ling et al., 2019; Novotná, 2019; Stender \& Stuhlmann, 2018a; Vongyai \& Noparit, 2019).

(Schoenfeld, 1992) explains four categories of individual activities in problem solving: knowledge, heuristic strategies, belief systems, and metacognition. Heuristic strategies are tools that narrowing the search of solutions for broad problems (Polya, 1957). Gelernter \& Rochester on (Kiong et al., 2017) define heuristic method as a procedure that possibly made a short cut to the goal, or may lead into a blind alley in finding a solution. (Ang \& Lau, 2019) states another opinion that heuristics is a strategy for solving complex problems in the form of stories/words. Slightly different from some of the opinions above, Blinkston in (Vongyai \& Noparit, 2019) defines a heuristic strategy as an innovative approach to learning where students develop their self-invitation and self-directed. The heuristic strategy in general is a tool in problem solving where the steps to solve the problem are sequential and have various types.

The heuristic strategy in learning by (Polya, 1957) consists of four stages: wondering/reading the problem, designing/exploring and select a strategy, investigating/solving, and discovering/looking back. Krulik \& Rudnick (1995) describe the heuristic strategy in many types: read and think, explore and plan, select a strategy, find an answer, reflect, and extend. In Singapore, the bar modeling strategy or drawing model is the most well-known heuristic strategy applicable in learning (Cavendish, 2020) while the heuristic strategy emphasized for Malaysian students are such draw a diagram followed by other strategies such as trial and error, identifying pattern, using equation or listing (Yew \& Zamri, 2016).

Several experts in mathematics learning have developed heuristic strategies (Tambunan, 2018). The heuristic strategy could be implemented in primary and secondary schools (Apostol, 2017; Singh et al., 2018). Heuristics intends to teach mathematical thinking so that students can experience the problem-solving process by themselves (Hughes, 1974). During application, the heuristics adjusted through the characteristics of students. Students who have not mastered problem solving yet, need explicit instructions to understand, execute, and evaluate a problem. For students who have understood various strategies but still unable to apply them in the problem-solving process, metacognitive strategies will help students to plan, sort, and monitor their thinking processes (Arum et al., 2019)

Heuristics in mathematics learning is foreseen to be openly implemented in Indonesia. These are reflected in Regulation of the Minister of Education and Culture of The Republic of Indonesia number 21 of 2016 where students are expected to have the ability to determine effective problem-solving strategies, evaluate results, and make announcements. By implementing heuristic strategies in learning, students can understand concepts and find solutions easier, also directly improve learning outcomes (Pramita \& Rusmayadi, 2018). Aside from the cognitive aspects, students' self-efficacy also can be increased (Apostol, 2017).

Wilson in (Kiong et al., 2017) suggested two different definitions of heuristics as a method of teaching and the use of heuristics as goals. Various challenges of teachers and students in applying heuristic strategies are found in several regions. Research in the Philippines by 
Table 1. Learning with Heuristic Strategies

\begin{tabular}{ll}
\hline Components & Indicators \\
\hline Teachers & 1. Understand about heuristic strategy in learning process \\
& 2. Make a group of students to work on problems given \\
3. Provide non-routine problems \\
4. Giving more time to students for think and identify the problems \\
5. Ask triggering questions to students (specifically for general idea to ignite \\
\\
6. Giscussion) \\
7. Give questions to test and see students' understanding of the problems \\
Students & 1. Identify the problems given (read and think) \\
& 2. Know various heuristic strategies to be used in solving a problem (explore \\
& 3. Choosing an appropriate heuristic strategy used in solving a problem (select \\
& 4. Solve problems with the chosen heuristic strategy (find an answer) \\
5. Present the work done (reflect and extend) \\
6. Discuss the work of other friends (reflect and extend) \\
7. Looking for alternative solutions using different strategies (reflect and \\
Learning kit \\
(worksheets) \\
1. Accommodate non-routine problems \\
2. Contains questions to test students' understanding of the problems \\
3. Contains questions that trigger students to think about problem-solving \\
\end{tabular}

Mobilangan et al (Apostol, 2017) shows the limited instruction about heuristics strategy in the classroom. Moreover, the types of problems given by teachers, with the utmost of routine problems similarly limited. Research in Jordan found that students and teachers consider heuristics to be separate from the problem-solving process. Students do not fully understand the basic idea that underlies the implementation of heuristics. Another study in Kazakhstan shows that the teacher has taught using the heuristic method, but they unaware of these defined as a heuristic (Nokhatbayeva, 2020).

Based on these different challenges from the different countries listed above, it is necessary to conduct a similar study in Indonesia, especially in Yogyakarta and Central Java Province. Heuristic learning is conducted to facilitate students in hone problem-solving skills. The implementation of learning will undoubtedly not work perfectly. This is moderately due to the constraints found on teachers. This research aims to describe the challenges experienced by teachers in implementing heuristic strategies.

\section{METHODS}

This empirical research was a qualitative study. This study tends to describe the challenges of implementing heuristic learning in mathematics from the teachers' perspective. The research was conducted in November - December 2020. The research participants were 12 mathematics teachers (5 male and 7 female) from 4 state Junior High Schools and 8 private Junior High Schools in Yogyakarta and Central Java Region. They are professional teacher with 3-10 years experiences in teaching mathematics. Samples were taken by purposive random sampling, considering at least 2 years experiences and still active as a teacher on each region's mathematics teacher working group (MGMP). Teachers' identity is remains hidden along with 
Table 2. Teachers' Understanding about Heuristic Strategies

Definition of Heuristic Strategies

Verification result

1. Learning strategies that emphasize students to find their own

Some teachers were unable to concept of learning material differentiate heuristic as

2. Learning strategies that emphasize learning activities to stimulate students to be active in the learning process

3. Learning strategies using critical thinking strategy, learning process, or method. However, some

4. Learning strategies that encourage students to have critical thinking skills and be able to solve problems in various ways teachers are aware of the that they understand

5. Learning mathematics in order to optimize students' abilities in solving word problems through sequential steps

6. Learning process that emphasizes critical thinking and analysis to find solutions of the problems

7. Learning process to find the solution of problems on their own

8. A sequence of learning activities that emphasize critical and analytical thinking processes to seek and find their answers to a question

9. Learning activities that emphasize critical and analytical thinking processes to seek knowledge

10. Repetitive learning

the responses from questionnaires. These are confidential and being coded to ensure that their responses were not affected participants' professions in the future. In the research process, teachers answering the questionnaire voluntarily. The researcher assured them that the data from the questionnaires were used solely for this research.

Data was collected through a questionnaire. The questionnaire consists of 18 items. Open-ended questions are used to provide actual answers encountered by teachers, especially as qualitative data. The questions were derived from synthetize process. Several supporting components influence the implementation of heuristic learning to be ideally implemented. These components are teachers as the facilitator, students as the subject of the learning process, and learning kits as a tool or aids in learning. The heuristic learning implementation described in the following indicators (see Table 1).

Data analyzed using the model of Miles and Huberman (1994) which is data reduction, data presentation, and conclusion/verification. The triangulation conducted by interview for some teachers to confirm their responses from the questionnaire. The responses were described and presented as a table based on the sub-themes. These sub-themes were: 1) Teachers' knowledge about heuristic strategy, 2) the challenges on implementing heuristic strategies, 3) the challenges on presenting non-routine problems to students, 4) the challenges faced by student on how to learn problem-solving strategies, 5) the challenges on how students' solving non-routine problems, 6) the challenges on students' discussion after implementing problemsolving strategies.

\section{RESULTS AND DISCUSSION}

The data obtained related to heuristic strategies in learning will be discussed in each sub-theme. The result and discussion about each sub-theme were explained later.

\section{Teachers' Knowledge about Heuristic Strategy}

Data reduction indicates that some teachers do not have good knowledge about heuristic strategy. Teachers have not been able to differentiate among strategies and learning methods. 
However, some teachers could explain the purpose and role of implementing heuristic strategies in learning, which are the strategies used to solve problems in sequence. The table of data reduction could be seen as follows (Table 2).

The heuristic strategy is a strategy used in solving non-routine problems, especially for word problems (Lester et al., 1989; Ang \& Lau, 2019). Teachers 3, Teacher 4, and Teacher 5 can explain the purpose of the heuristic strategy by stating that heuristic strategies are used to solve problems. Also, Teacher 3 has marked that heuristics are done sequentially/based on a certain algorithm. This shows that teachers need to enhance their perception of the definition of heuristic strategies to be used in mathematics learning. The clear definition will affect the teachers' actions in managing the class considering that some experts define heuristics in different terms, such as heuristics as an approach to learning (Kusdinar, 2020) or heuristics is a problem solving strategy (Kusdinar et al., 2017; Tambunan, 2018; Vongyai \& Noparit, 2019).

Teachers' understanding of heuristic strategies needs to be developed. One of the possible extents is to manage the training on the implementation of heuristic strategies for mathematics teachers. A research by (Stender \& Stuhlmann, 2018) conducted training for prospective mathematics teacher, students, and received positive feedback. The results of the training were beneficial for those who have taught in schools. The training also involves how to practice heuristic strategies in certain materials which hardly any connect to school mathematics.

\section{The Challenges on Implementing Heuristic Strategies}

Based on the data, 9 out of 12 teachers have already implemented heuristic strategies in the learning process, and 1 teacher were implementing heuristic strategies sometimes. According to the teacher, the implementation of heuristic strategy cannot be spared of facing the obstacles in the process. Several teachers conveyed several obstacles, covering the complexity of the material, student characteristics, up to technical matters that supported learning. The results of data reduction are presented in Table 3.

Table 3. Challenges on Implementing Heuristic Strategies

\begin{tabular}{|c|c|}
\hline Challenges on Implementing Heuristic Strategies & Verification result \\
\hline $\begin{array}{l}\text { 1. Heuristic methods were difficult to implement on this remote } \\
\text { learning } \\
\text { 2. Complexity of the materials and students' characteristics for } \\
\text { being slow to understand made me thinking about implement } \\
\text { heuristic strategies in some materials and prefer to use } \\
\text { expository strategies instead } \\
\text { 3. The time limit while the materials is complex } \\
\text { 4. Students being less active in learning }\end{array}$ & $\begin{array}{l}\text { The challenges encountered by } \\
\text { teachers were about the } \\
\text { complexity of the materials, } \\
\text { students characteristics, and } \\
\text { the limited time for } \\
\text { implementing heuristic } \\
\text { strategies }\end{array}$ \\
\hline
\end{tabular}

In general, the implementation of heuristic strategies in learning encounters several obstacles. According to teachers who have never or rarely used a heuristic strategy (Teacher 1 and Teacher 2), complex material and limited time became a consideration for not applying the heuristic strategy. Teachers have to follow the curriculum regarding materials and the time for finishing each material in the class. Some teachers focused on completing the basic contents before giving non-routine problems to students, as stated by Teacher 2 , Teacher 6 , and Teacher 7. Another teacher explained that students are practicing heuristic while there still time left and just sometimes. However, Teacher 1 already uses non-routine problems in the apperception stage of learning to attract students' interest. In general, data shows that the heuristic strategy 
in the learning process is still not being priority unless this strategy tends to train students' problem-solving skills. This concern needs to be addressed, because problem solving is one of the competencies that students must have, especially Indonesian students (Regulation of the Minister of Education and Culture of The Republic of Indonesia number 22 of 2016). Besides, (Lucas, 1974) states that students who get heuristic training exhibited superior performance in problem solving. They have a better understanding of problems, using the right strategy, to getting accurate solutions. If students have good problems-solving skills, then they were most likely to have a good academic

Student characteristics also one of the challenges, since students have a different pace of learning, especially in solving non-routine problems. (Lester et al., 1989) explain the main reason why problem solving is difficult for student. Problem solving is a complex cognitive activity that requires some knowledge and skill, not just a direct application of mathematics. Train students to learn heuristics takes a long time (Stender \& Stuhlmann, 2018). Because of that, teachers need to familiarize students with trying various examples of problems to be done by different strategies (Gurat, 2018).

\section{The Challenges on Presenting Non-Routine Problems to Students}

Learning with a heuristic strategy originates by giving non-routine problems to the students. In its application, teachers experience barriers in the process. Most of the teachers highlighted the students' ability to solve problems. Students have different abilities in understanding problems. Also, students' low prior knowledge and literacy skills become other challenges when teachers give non-routine problems. Giving complex problems seems to reduce student motivation in problem solving. In more detail, data reduction is presented in Table 4.

Table 4. Challenges on Presenting Non-Routine Problems to Students

\begin{tabular}{|c|c|}
\hline Challenges on Presenting Non-Routine Problems to Students & Verification result \\
\hline $\begin{array}{l}\text { 1. Low student input (refer to cognitive skill) in mastering basic } \\
\text { concept of mathematics and problem-solving abilities } \\
\text { 2. Heterogeneous students' abilities for achieving basic } \\
\text { competencies } \\
\text { 3. Low literacy on the students, some of them do not understand } \\
\text { the concept } \\
\text { 4. The knowledge of students is still not comprehensive } \\
\text { 5. Students don't explore themselves more, sometimes they don't } \\
\text { want to repeating previous materials } \\
\text { 6. The complex problem chosen make students' motivation } \\
\text { reduced } \\
\text { 7. How to understand students' thinking, and how to use the } \\
\text { familiar word to provoke students' thinking }\end{array}$ & $\begin{array}{l}\text { The challenges of this process } \\
\text { related into three main aspects: } \\
\text { students' ability in cognitive } \\
\text { and psychological aspect, } \\
\text { characteristics of problems, and } \\
\text { teachers' way to understand } \\
\text { students' thinking }\end{array}$ \\
\hline
\end{tabular}

The researcher found an interesting point. All of the teachers admitted that they were facing some challenges. The challenge mainly because of the low students' cognitive skills and mathematics contents. Students with diverse abilities cannot be generalized. Giving problems might affect low students on their cognitive abilities but also on psychological factors. Teacher 1 appended that complicated problems could decrease students' motivation. This will disrupt the learning process of students. Students' motivation can foster their willingness in learning (Emda, 2017). Teacher must always encourage them to understand the concepts so that their motivation and interest will increase (Arivina \& Retnawati, 2020). 
Teacher 5 encountered the obstacles to providing non-routine problems to put on the way students thought. It is hard to pick the words that easy for students to understand so that students' thoughts in problem solving are triggered. (Celik \& Guzel, 2017) states that teachers' knowledge of student thinking is important in understanding and supporting students. Teachers that understand students' thinking most likely having better knowledge to identify the difficulties experienced by students.

\section{The Challenges Faced by Student on How to Learn Problem-Solving Strategies}

The teacher trains heuristic strategies with particular techniques. Teacher 1 and Teacher 8 used guided questions and interviews to trigger students to think. Teacher 2 and Teacher 5 used different approaches, such as providing examples of solving similar problems and writing them down in steps. Teacher 6 guides students to forms a group to explore the task. Teachers adjust the method of heuristic learning by considering the material to be studied. Most of the teachers encountered some constraints in this learning process. The obstacles faced include technical, students 'cognitive ability, and students' psychological matters that occur in the learning process. Table 5 presents the data reduction on this sub-theme.

Table 5. Challenges on Learning Problem-Solving Strategies

\begin{tabular}{|c|c|}
\hline Challenges on Learning Problem-Solving Strategies & Verification result \\
\hline 1. The internet connection & \multirow{7}{*}{$\begin{array}{l}\text { The challenges according to the } \\
\text { teachers on learning problem- } \\
\text { solving strategies specify into } \\
\text { three parts, which is technical } \\
\text { constraints, the psychological } \\
\text { factor of student for being afraid } \\
\text { and less interest, and students' } \\
\text { cognitive ability }\end{array}$} \\
\hline $\begin{array}{l}\text { 2. Sometimes the instructions given are not clear enough that it } \\
\text { takes students quite times to understand them }\end{array}$ & \\
\hline 3. Lack of students' interest in learning & \\
\hline $\begin{array}{l}\text { 4. Most students only work with strategies written in the book and } \\
\text { afraid/not taking attempt to use other methods, especially when } \\
\text { asked to explain }\end{array}$ & \\
\hline $\begin{array}{l}\text { 5. Students facing problems with different/various kinds of } \\
\text { solving strategies, so students have to think critically. Students } \\
\text { are confused and do not know how to solve these problems. }\end{array}$ & \\
\hline 6. Students with lower abilities severe to solve problems & \\
\hline $\begin{array}{l}\text { 7. Not all students have good critical thinking skills and deep } \\
\text { knowledge }\end{array}$ & \\
\hline
\end{tabular}

Teachers experience technical problems such as the internet network, conceding that today's education was conducting remote learning. Implementation of remote learning sometimes turns into an obstacle because heuristics learning becomes disturbed. Teachers find it difficult to monitor student activities, while heuristic learning requires the active participation of students. Students without having internet network will miss the opportunity to inquire (Dhawan, 2020). Additionally, teachers experience technical obstacles when students need more time to understand the instructions given. The time available is limited for studying heuristics, while the process of learning heuristic strategies is long lasting (Lester et al., 1989; Stender \& Stuhlmann, 2018b). The teacher needs to provide many examples of each strategy so that students can identify and use them to solve problems appropriately. This can help them to explore the problem and be encouraged to reflect on their work.

The findings from Teacher 5 imply that teachers need to provide alternative explanations if they confront new material and new problems that have never been encountered. In this case, (Mousoulides \& Sriraman, 2014; Chapman, 2015) have emphasized that teachers need to 
provide correct feedback for students who use various approaches to solving problems. The teacher must have confidence, experience, and self-awareness so they can solve problems without even knowing the exact answer.

\section{The Challenges on How Students' Solving Non-Routine Problems}

In heuristic learning, students should solve non-routine problems. Most of the teachers make a group of students so that the students could discuss each other. In opposite, Teacher 3 was not assigning students into a group because of online learning. Teacher 4 often used the classical discussion method so the students can ask and respond to each other in a class. The teacher thought that the time allocation was insufficient to solve problems. According to Teacher 2 and Teacher 10, discussing and understanding the problems activities take the most time. Meanwhile, Teacher 7 states that the process of teaching heuristic strategies takes a lot of time. Several obstacles were faced by the teacher, such as lack of students' enthusiasm and the current pandemic situation which resulted in insufficient time to solve problems. For details, the data reduction can be seen in Table 6 .

Table 6. Challenges on Students' Solving Non-Routine Problems

\begin{tabular}{|c|c|}
\hline Challenges on Students' Solving Non-Routine Problems & Verification result \\
\hline 1. Different student starting points sometimes hindered problem & Constraints appear at the \\
\hline & beginning, in the middle, and at \\
\hline $\begin{array}{l}\text { 2. Students cannot identify the type/name of the strategy they use } \\
\text { and write down something that crosses their thinking. }\end{array}$ & $\begin{array}{l}\text { the end of the problem-solving } \\
\text { process }\end{array}$ \\
\hline 3. Students are not familiar to solving non-routine problems & \\
\hline $\begin{array}{l}\text { 4. Most students hesitate to solve problems on their own because } \\
\text { they get used to being guided. Students had no confidence } \\
\text { while teachers asking them about the strategy }\end{array}$ & \\
\hline $\begin{array}{l}\text { 5. Some students have different characteristics and level of } \\
\text { understanding in problem solving }\end{array}$ & \\
\hline $\begin{array}{l}\text { 6. Students feeling difficult in making mathematical model so } \\
\text { they confused on which concept used to solve the problems }\end{array}$ & \\
\hline $\begin{array}{l}\text { 7. Students were not finishing the solution sometimes because } \\
\text { they often forget the following process. They used mixed } \\
\text { strategies in some questions. }\end{array}$ & \\
\hline
\end{tabular}

The teacher provides an overview of the obstacles experienced by students in problem solving (Table 6). In the first steps, obstacles arise when students have different starting points (Teacher 1). Teacher 2 also conveyed the same thing, where students have different methods of problem solving. To overcome this obstacle, teachers need to help student in terms of giving them the feedback, so that they could identify the challenges (Haankuku, 2018). In 2013 Curriculum learning, teachers can do this at the apperception stage. Based on Teacher 11 and Teacher 12, students find it hard to change word problems into a mathematical model. This could lead them into difficulties in understanding the problems. Students cannot determine accurate concepts and strategies to solve problems (Mairing, 2017). Teachers need to provide more opportunities for students to practice in problem solving in the class (Lester et al., 1989). Besides, teachers need to consider the students' affective aspects. Teacher 5 revealed that students were not confident in describing the strategy used to solve problems. The main factor was that students were getting used to escort by teachers. Several methods to overcome this, such as give problems related to their daily life. The selection of real-world problems is one of the important pillars in constructivist teaching (Bibi et al., 2019). 
Rosyada, M. N., \& Retnawati, H.

\section{The Challenges on Students' Discussion in Implementing Problem- Solving Strategies}

One of the principles of heuristic learning is to group students into small groups. Students solve problems using the appropriate heuristic strategy. After getting a solution, the next step is to present the results to other friends. The teacher encountered obstacles in its implementation. Data reduction is shown in Table 7.

Table 7. Challenges on Discussion in Implementing Problem-Solving Strategies

\begin{tabular}{ll}
\hline $\begin{array}{l}\text { Challenges on Discussion in Implementing Problem-Solving } \\
\text { Strategies }\end{array}$ & Verification result \\
\hline $\begin{array}{l}\text { 1. Passive students, only a few students actively asked } \\
\text { questions. }\end{array}$ & $\begin{array}{l}\text { From the students' side, they are } \\
\text { less active and do not understand } \\
\text { the topic of discussion. From the }\end{array}$ \\
2. Heterogeneous students' ability & $\begin{array}{l}\text { teachers' point of view, difficulties } \\
\text { 3. Students do not understand what will be discussed. } \\
\text { 4. Teachers have difficulty in encouraging students to ask } \\
\text { in getting students to discuss } \\
\text { actively }\end{array}$ \\
\hline
\end{tabular}

The majority of the teachers revealed that the obstacle in the discussion was passive students. Only a few students actively asked and responded to questions. This is certainly must be considered. Heuristic learning is supposed to be held as collaborative (in groups). They trained to have responsibility, listen to each other, and share various strategies used to solve the tasks given by teachers (Warner \& Kaur, 2017). Students who work in groups can support and discuss with each other (Stender \& Stuhlmann, 2018b). Even on the different group, these conditions could happen. The discussion helped students to correct some mistakes and by that, the correct answers or conclusion could be reached (Božić, 2019).

Teachers as a facilitator are bound to monitor the discussion and direct students on problem solving using the right strategy. In addition, teachers also need to guide students to be able to explain the process of finding solutions. However, this research has shown that teachers feel difficult to encourage students to ask questions or give opinions. As discussed in the previous sub-theme, the teacher has to master multiple heuristic strategies and be able to identify where students feel troublesome (Chapman, 2015). That way, students are helped in using the right strategy and successfully find solutions to the problems given.

\section{CONCLUSIONS}

It appeared that several junior high schools in the Yogyakarta Special Region and some of Central Java already implementing heuristic learning. Despite that, some teachers define a heuristic strategy improperly. In its implementation, the teacher encountered various obstacles. This research explained several constraints in each learning stage, including the complex material and limited time, diverse student abilities (most students have not mastered concepts, strategies, and problem-solving abilities), low affective aspects of students (motivation, interest, and self-confidence) in dealing with non-routine problems, the lack of teachers' ability in understanding students' thinking and using simple sentences that are familiar with students, technical factors arise in online learning, students do not accustom to solving non-routine problems, a low level of student activity during the discussion process, and teachers who have difficulty getting students to actively ask questions and give opinions. 
Training for the application of learning with heuristic strategies is expected in the future. Teacher needs to apply a learning approach to foster students' motivation and interest towards heuristic strategy, understand and support students in problem solving, familiarize student to working on real life problems, and provide heuristic examples also correct feedback whenever students is asking to. These research results are anticipated to be the reference for further research, to focus on solutions that can be applied to undertake the various obstacles in implementing heuristic strategy. Other research can be done to find the solutions for the challenges of the implementation of heuristics strategy in this research.

\section{AUTHOR CONTRIBUTIONS STATEMENT}

MNR worked as the main drafter in this research. data collection and instrument design assisted by HR.

\section{REFERENCES}

Abdullah, A. H., Shin, B., Kohar, U. H. A., Ali, D. F., Samah, N. A., \& Ashari, Z. M. (2019). A comparative study of teaching problem-solving in mathematics secondary schools in Malaysia and South Korea. In 2019 IEEE International Conference on Engineering, Technology and Education (TALE) (pp. 1-8). IEEE.

Ang, M., \& Lau, E. (2019). How to raise an intelligent child. Seriously Addictive Mathematics.

Apostol, E. M. D. (2017). Problem solving heuristics on non-routine problems of college students. American Journal of Educational Research, 5(3), 338-343.

Arivina, A. N., \& Retnawati, H. (2020). Constraints of high school mathematics teachers in teaching distance and angle material in three dimensions. Journal of Physics: Conference Series, 1511(1).

Arum, R. P., Widjajanti, D. B., \& Retnawati, H. (2019). Metacognitive awareness: How it affects mathematical problem-solving process. Journal of Physics: Conference Series, $1320(1)$.

Bibi, A., Ahmad, M., Shahid, W., Zamri, S. N. S., \& Abedalaziz, N. A. M. (2019). An Evolving research to tackle teaching and learning challenges during differential equations course: a combination of non-routine problems and teacher training. International Electronic Journal of Mathematics Education, 15(1), 647-656.

Božić, R. (2019). The application of modern technology in teaching and learning stereometry. In Scientific Conference "Research in Mathematics Education (pp. 102-111).

Cavendish, M. (2020). Math in Focus ${ }^{\circledR}$ : Singapore Math ${ }^{\circledR}$ by Marshall Cavendish $®$.

Celik, A. O., \& Guzel, B. E. (2017). Mathematics teachers' knowledge of student thinking and its evidences in their instruction. Journal on Mathematics Education, 8(2), 199-210.

Chapman, O. (2015). Mathematics teachers' knowledge for teaching problem solving. Lumat: International Journal of Math, Science and Technology Education, 3(1), 19-36.

Dhawan, S. (2020). Online learning: A panacea in the time of COVID-19 crisis. Journal of Educational Technology Systems, 49(1), 5-22.

Emda, A. (2017). Kedudukan motivasi belajar siswa dalam pembelajaran. Lantanida Journal, 
$5(2), 172-182$.

Gurat, M. G. (2018). Mathematical problem-solving strategies among student teachers. Journal on Efficiency and Responsibility in Education and Science, 11(3), 53-64.

Haankuku, U. N. (2018). Challenges of learning mathematics by distance a case study of public and private Universities in Zambia. International Journal of Science and Research (IJSR), 7(9), 926-933.

Hughes, B. B. . (1974). Heuristic teaching in mathematics. Educational Studies in Mathematics, 5(3), 291-299.

Irhamna. (2017). Efektivitas penggunaan strategi krulik dan rudnik dalam meningkatkan kemampuan pemecahan masalah matematis. Seminar Nasional Matematika, 321-325.

Kemendikbud. (2016). Permendikbud Nomor 21 Tahun 2016 Tentang Standar Isi Satuan Pendidikan Dasar dan Menengah. Jakarta: Kemendikbud.

Kemendikbud. (2016). Permendikbud Nomor 22 Tahun 2016 Tentang Standar Proses Satuan Pendidikan Dasar dan Menengah. Jakarta: Kemendikbud.

Kiong, P. L. N., Yong, H. T., Hoe, L. S., \& Ying, L. C. (2017). Will heuristics enhance the success of mathematics problem solving? 1-11.

Kusdinar, U. (2020). Efforts to increase the understanding of algebraic concepts by using the vee heuristic strategy. International Journal of Scientific and Technology Research, 9(2), 6502-6505.

Kusdinar, U., Sukestiyarno, S., Isnarto, I., \& Istiandaru, A. (2017). Krulik and rudnik model heuristic strategy in mathematics problem solving. International Journal on Emerging Mathematics Education, 1(2), 205-210.

Lester, F. K., Garofalo, J., \& Kroll, D. L. (1989). The role of metacognition in mathematical problem solving: A study of two grade seven classes.

Ling, C. Y., Osman, S., Daud, M. F., \& Hussin, W. N. W. (2019). Application of vee diagram as a problem-solving strategy in developing students' conceptual and procedural knowledge. International Journal of Innovative Technology and Exploring Engineering, 8(10), 2796-2800.

Lucas, J. F. . (1974). The teaching of heuristic problem-solving strategies in elementary calculus. Journal for Research in Mathematics Education, 5(1), 36-46.

Mairing, J. P. (2017). Students' abilities to solve mathematical problems according to accreditation levels. International Journal of Education, 10(1), 1-11.

Mousoulides, N., \& Sriraman, B. (2014). Heuristics in mathematics education. In Encyclopedia of Mathematics Education (S. Lerman, pp. 521-525). Springer Science+Business Media.

NCTM. (2000). Principles and standards for school mathematics. www.nctm.org

Nokhatbayeva, K. (2020). The effects of heuristic teaching methods in mathematics. Proceeding of International Young Scholars' Workshop, 9, 142-156.

Novotná, J. (2019). Bridging two worlds-Cooperation between academics and teacherresearchers. In Scientific Conference "Research in Mathematics Education” Proceedings 
(pp. 5-15).

Polya, G. (1957). How to solve it. Princeton University Press.

Pramita, D., \& Rusmayadi, M. (2018). Pengaruh strategi heuristik pada pendekatan pemecahan masalah dalam pembelajaran matematika kelas VIII SMP. JTAM| Jurnal Teori Dan Aplikasi Matematika, 2(2), 157-161.

Schoenfeld, A. H. (2016). Learning to think mathematically: Problem solving, metacognition, and sense making in mathematics (Reprint). Journal of education, 196(2), 1-38.

Scott, L. A. (2017). 21st century skills early learning framework. Partnership for 21 st Century Skill (P21).

Singh, P., Teoh, S. H., Cheong, T. H., Md Rasid, N. S., Kor, L. K., \& Md Nasir, N. A. (2018). The use of problem-solving heuristics approach in enhancing STEM students development of mathematical thinking. International Electronic Journal of Mathematics Education, 13(3), 289-303.

Smit, L. S. (2016). A better understanding of 21st century skills in mathematics education and a view on these skills in current practice. In Research Project (30 ECTS).

Stender, P., \& Stuhlmann, S. (2018a). Fostering heuristic strategies in mathematics teacher education. INDRUM Network, 1-10.

Stender, P., \& Stuhlmann, S. (2018b). Heuristic strategies in mathematics teacher education. INDRUM Network, 1-10.

Syahlan. (2017). Sepuluh strategi dalam pemecahan masalah matematika. Indonesian Digital Journal of Mathematics and Education, 4(6), 358-369.

Tambunan, H. (2018). Impact of heuristic strategy on students' mathematics ability in high order thinking. International Electronic Journal of Mathematics Education, 13(3), 321328.

Vongyai, A., \& Noparit, T. (2019). Using heuristic strategies to promote mathematics problem solving ability of grade 10 students. PEOPLE: International Journal of Social Sciences, 5(1), 952-968.

Warner, S., \& Kaur, A. (2017). The perceptions of teachers and students on a 21 st century mathematics instructional model. International Electronic Journal of Mathematics Education, 12(2), 193-215.

Yew, W. T., \& Zamri, S. N. A. S. (2016). Problem solving strategies of selected pre-service secondary school mathematics teachers in Malaysia. MOJES: Malaysian Online Journal of Educational Sciences, 4(2), 25-31. 